\title{
New radiocarbon dates from Ireland
}

\author{
A. G. SMITH, J. R. PILCHER and G. W. PEARSON
}

\begin{abstract}
$\operatorname{Dr}$ A. G. Smith is one of the Directors of the Palaeoecology Laboratory of Queen's University, Belfast. A great part of the work of the Belfast radiocarbon dating laboratory, which is in the charge of $\operatorname{Mr} G$. W. Pearson, has so far been connected with environmental studies. A number of dates have been obtained, however, from archaeological contexts. In this article, written with two colleagues in the Laboratory, the archaeological dates are summarized and an outline given of the palaeoecological work in a more reasoned and coherent form than the published date lists

(Smith, Pearson and Pilcher, I970; and forthcoming).
\end{abstract}

Many of the archaeological samples dated have been charcoal.* This has been most rigorously pre-treated to remove contamination by rootlets and humic material. The dates have been obtained by gas-proportional counting of methane. The results are reported as conventional radiocarbon dates using the 5570 year half-life.

\section{NEOLITHIC SITES}

The oldest dates obtained, so far, are from a series from A. M. ApSimon's excavations at Ballynagilly Td., Co. Tyrone (ApSimon, I969a). The dates are: $3675 \pm 50$ bc (UB-197) from charcoal in a pit containing hearth debris and sherds of Neolithic pottery a few metres away from the Neolithic rectangular house. Secondly, $3795 \pm 90$ bc (UB-305), from charcoal in a hearth in the Neolithic occupation area. Thirdly, $3690 \pm 90$ bc (UB-307) from charcoal in a pit with early Neolithic pottery, sealed by sterile sand. These dates, whose means fall between 3700 and $3800 \mathrm{bc}$, are older than any so

*We should like to thank our colleagues who have cooperated in providing well-documented material for dating and in discussing with us the significance of the results. In particular we thank $\mathrm{Mr}$ A. M. ApSimon who has read the manuscript and made valuable suggestions.

$\uparrow$ Following the lead of Suess and Strahm (Antiquity, XLIV, 93) we have adopted Dr D. Shove's suggestion of denoting conventional radiocarbon ages on the Christian calendar scale by lower case letters. far obtained for Neolithic material in the British Isles. Nevertheless, they form a consistent group and it will be of great interest to see whether dates in this range are obtained from other sites. Meanwhile, it is worthy of mention that in the Lower Bann Valley, at Ballyscullion, the later part of a brief phase of forest clearance distinguished in a detailed pollen diagram (Smith and Crowder, unpublished) has been dated by radiocarbon to $3580 \pm 60$ bc (UB-II6). This clearance took place several centuries before the landnam clearance usually associated with the Early Neolithic and dated at the same site to $3180 \pm 60$ bc (UB-II5).

A landnam phase has also been discovered at the Ballynagilly site. The beginning of the clearance, at a level where pine charcoal is present and the pine pollen curve declines, has been dated to $3195 \pm 70$ bc (UB-253). In another part of the site, oak charcoal stratified into peat deposits, at a level of a decline of oak pollen, has been dated to $3245 \pm 60 \mathrm{bc}$ (UB-I 5). Hazel charcoal under a layer of re-deposited sand has been dated to $3345 \pm 90$ bc (UB-r 8 ). It seems clear that the forest clearance was the work of builders of the rectangular house. The charred remains of the split-oak planking forming the walls of this house have been dated to $3215 \pm 50 \mathrm{bc}$ (UB-201) and charcoal from a posthole inside the house to $3280 \pm 125 \mathrm{bc}$ (UB-r99).

Other dates from Neolithic contexts at 


\section{ANTIQUITY}

Ballynagilly are: $3420 \pm 85$ bc (UB-304) for charcoal from a pit sealed by a layer containing Neolithic artifacts; $2960 \pm 90$ bc (UB-30I) for charcoal in a pit containing Neolithic artifacts. A third date of 2930 土 I Io bc (UB-306) was obtained for charcoal found in close association with Middle Neolithic pottery resembling the Murlough variety of Sandhills ware (Case, I961; 1969) with features reminiscent of Carrowkeel ware. The Early Neolithic pottery from the site resembles the Ballymarlagh style of Case (1961, 176) but further study is required before it can be determined whether the group of very early dates mentioned above (UB-305, UB-307, UB-197) is paralleled by any differences in the associated artifacts.

Samples of charcoal have been dated from four Neolithic cairns: two court-cairns, a passage grave and a cairn containing a portal dolmen. The passage grave is at the well-known site of Knowth in Co. Meath being excavated by G. Eogan (Eogan, I968). Neolithic samples from the main mound have not yet been assayed, but one of the satellite graves has been dated. Charcoal from under the mound of this grave, obtained and pre-treated by P. Q. Dresser, gave dates of $2925 \pm 150$ bc (UB-3I 8 ) and $2845 \pm 185$ bc (UB-319). A secondary occupation on the main mound of the passage grave, in an area of disturbance thought to be connected with a souterrain, has been dated to ad $75^{\circ} \pm 70$ (UB-299).

The first court-cairn is that at Annaghmare, Co. Armagh, excavated by D. M. Waterman (Waterman, 1965). Of three determinations only one is acceptable as dating the structure. This is $2445 \pm 55$ bc (UB-24I) for charcoal sealed behind the primary blocking of the forecourt. The two other dates: ad $35^{\circ} \pm 60$ (UB-240) for charcoal from chamber 2 , and ad $525 \pm 5 \circ$ (UB-209) for charcoal from chamber 3 , seem to imply intrusion of later charcoal though there was no evidence of disturbance. The second court-cairn is that at Ballymacdermot, Co. Armagh, excavated by A. E. P. Collins and B. C. S. Wilson (Collins and Wilson, 1964). Charcoal from a black deposit below the stone blocking of the inner forecourt gave a date of $1710 \pm 60 \mathrm{bc}(\mathrm{UB}-207)$. This date is several centuries younger than would be expected for a court-cairn. It would, however, be in accordance with an Early Bronze Age date for the flat-bottomed pottery from the layer dated. A date has been obtained for charcoal from a stratum incorporated in the body of the cairn of Ballykeel portal dolmen, Co. Armagh, excavated by A. E. P. Collins (Collins, 1965). This date, $1400 \pm 45 \mathrm{bc}$ (UB-239), is also somewhat younger than expected. It emphasizes the importance of dating several samples from a site and the urgent need to obtain critical material for dating from a wide range of chamber tombs.

The Neolithic ritual site at Goodland, Co. Antrim, excavated by $\mathrm{H}$. Case (Case, $196 \mathrm{I}$ ), has been the subject of two previous attempts to obtain an applicable radiocarbon date. The Dublin laboratory obtained a date of $2200 \pm 200$ bc (D-46, Watts, 196r; McAulay and Watts, r96r) for the humus and basal peat which 'formed centrally over the shrine ... after its abandonment' (Case, 196r, 212). A much younger, and enigmatic, date of $75^{\circ} \pm 120 \mathrm{bc}$ was obtained for charcoal from one of the ritual pits by the Lamont laboratory (L-472a, Olson and Broecker, 196r). For the new determination the entire filling of one of the ritual pits was skilfully separated in the laboratory by P. Q. Dresser into three fractions. The fine charcoal particles gave a date of $2625 \pm \mathrm{r} 35 \mathrm{bc}$ (UB-320E). The mean of this determination falls near the end of the Middle Neolithic and the beginning of the Late Neolithic distinguished by Case (196r; 1969). The date appears, then, to be the first acceptable determination for the site and for the mature Sandhills Ware. The two other fractions separated from the pit-filling were humic acid, which was dated to $240 \pm 65$ ad (UB-320C), and rootlet material which was dated to $1065 \pm 80$ ad (UB-320G). These two determinations show dramatically the effect of downwashed humus and penetration by roots; they emphasize again that the nature and origin of the sample taken in the field needs to be fully understood.

At Ballynagilly, forest clearance has been detected by pollen analysis and associated by means of the radiocarbon dates with the builders 


\section{NEW RADIOCARBON DATES FROM IRELAND}

of the rectangular house. We have seen that there is evidence from the pollen diagrams and the charcoal in the peat that both oak, and more importantly, pine, were felled. In this case, we have discovered the charcoal from the Neolithic clearance fires. A date from another area opens the prospect that we may eventually discover the actual trees that were cleared. This date, $2955 \pm 85$ bc (UB-29I), was obtained from the outer part of a horizontal pine trunk embedded in the basal layer of the blanket peat that covers the Antrim plateau near Cushendall. The trunk is, however, exposed only in a quarry section and it has so far not been possible to determine whether or not it bears any signs either of working or burning.

\section{BRONZE AGE SITES}

Four dates have been obtained from Bell Beaker contexts. They are from three separate sites within the area excavated by A. M. ApSimon at Ballynagilly, Co. Tyrone. Preliminary examination of the pottery suggests contributions from European Bell, Wessex/Middle Rhine and Early Northern British Beaker tradition. The dates agree closely; they are: $2010 \pm 75$ bc-hearth charcoal enclosing Beaker sherds (UB-316)

$1955 \pm 120 \mathrm{bc}$-charcoal from a hearth pit in a Beaker habitation area (UB-200)

I $955 \pm 75$ bc-charcoal from a burnt area with Beaker pottery (UB-356)

$1900 \pm 55 \mathrm{bc}$-charcoal closely associated with Beaker sherds in a pit (UB-309)

The changes in the pollen diagram at approximately 2000 bc suggest clearance of birch scrub and possible emphasis on cereal-growing. (This date is taken from a deposition rate curve based on a large number of $\mathrm{C}_{4} 4$ dates.)

Charcoal from a mass containing a sherd of an 'Irish Bowl' (cf. ApSimon, I969b), and resting on burnt sandy clay with Beaker artifacts, has given a date of $1640 \pm 60 \mathrm{bc}$ (UB-I98). Three other dates have been obtained from Early Bronze Age contexts; in each case 'plain ware' was closely associated with the charcoal dated. The dates form a consistent group with means between 1500 and $1600 \mathrm{bc}$. They are: $1505 \pm$ 60 bc (UB-314), I530 \pm 80 bc (UB-3I5) and
1 $575 \pm 75$ bc (UB-355). This Early Bronze Age occupation at Ballynagilly appears to be connected with forest clearance, particularly of birch. At the same time there is an increase of plantains in the pollen diagram suggestive of an emphasis on pastoral farming. These changes, in an horizon containing charcoal, have been dated to $1670 \pm 60$ bc (UB-247).

The ubiquitous blanket peat of the north Irish uplands, which finally covered the Ballynagilly site, has provided a number of radiocarbon dates of archaeological interest. Some $7 \mathrm{~km}$. west of Ballynagilly, on the opposite side of a ridge rising to some $400 \mathrm{~m}$., lies the intriguing series of stone circles and alignments at Beaghmore (May, I953; Pilcher, 1969). A sample from the base of the peat which covered the monument until it was exposed by turfcutters, has been separated into four fractions by P. Q. Dresser, all of which have been dated. The oldest, and presumably most reliable, of the dates, is that for the particulate fraction of $325 \pm 65$ bc (UB-26ID). A date for the basal peat formed in the ditch of a newly-discovered cairn (cairn 10, Pilcher, 1969), however, falls some centuries earlier and provides a closer upper limit for the construction of the circles. This date is $775 \pm 55$ bc (UB-I63). A lower limit for the construction of the circles is given by charcoal from the old land surface below the mound of cairn Io, which gave a date of $1535 \pm 70 \mathrm{bc}$ (UB-I I). It is natural to think that the circles were constructed in the earlier part of the bracket. A number of flint cores were found associated with sizeable lumps of charcoal in the stony soil beneath the blanket peat. This charcoal, dated to $\mathrm{I} 605 \pm 45$ bc (UB-23), possibly belongs to the earlier part of the bracket for the stone circles.

A single sample has been dated from the prehistoric occupations on Coney Island, Lough Neagh, excavated by P. V. Addyman (Addyman, 1965). This sample, part of a large series from the site, was associated with Irish Bowl pottery. The date, I400 \pm 80 bc (UB-43) seems rather young for this pottery and in isolation is not of great significance.

Pollen analytical work by Mrs A. Goddard, on the blanket peats of north Antrim, shows that 


\section{ANTIQUITY}

during the Bronze Age a number of interesting and varied vegetational changes took place. At Beaghs Td., for instance, some eight $\mathrm{km}$. west of Cushendall, hazel scrub appears to have disappeared at a level dated to $1755 \pm 65 \mathrm{bc}$ (UB-346). At Gruig Top, in the same area, the pollen analytical evidence indicates a transition from scrub to heath between levels dated to $\mathrm{I}_{42} \pm 75$ bc (UB-339) and $\mathrm{I}_{3} 85 \pm 70$ bc (UB-364F). While scrub was eventually superseded by blanket bog in some places, there is evidence that the scrub woodland which characterizes the steeper slopes of the Antrim plateau today has persisted as such at least from Bronze Age times. At Crocknamoyle, near Cushendall, for instance, hazel scrub appears to have been in existence for almost three millennia.

In the same area, a radiocarbon-dated pollen diagram has been obtained from the blanket peat and sub-soil at Loughaveema, the disappearing lake. The local woodlands had evidently given place to rough pasture before a level dated to $125 \pm 70$ bc (UB-334). The samples came from within a few metres of the peat-covered cairn excavated by V. B. Proudfoot (unpublished) which contained a cist with an Irish Bowl. Neolithic hearths were found in the pre-peat soil.

Blanket peat also virtually covered the round barrow at 'The Pubble' in Loughermore Td., near Limavady in Co. Londonderry, which was excavated by Miss C. Warhurst in 1968. A series of more than twenty radiocarbon dates has been obtained for this site both in an attempt to date the monument and in connexion with palaeoecological work. The full details of this dating and other work will be published elsewhere. Bracketing dates have been obtained using samples from the old land surface and from the bottom of the peat-filled ditch. One of the dates which provide the lower limit for the construction of the barrow is $1885 \pm 80$ bc (UB- $195 \mathrm{~F}$ ), for the fine particulate fraction of the peaty soil beneath the tail of the outer bank. Closely comparable with this is the date of 1925 \pm 85 bc (UB-rgrE), for charcoal from the old land surface under the central mound. The humic acid from this old land surface has given a date of $1610 \pm 60 \mathrm{bc}(\mathrm{UB}-\mathrm{rg} \mathrm{IC})$. Since at this particular point there is evidence from other dates that there was no downwash of humic acids, this humic acid date may provide a closer lower limit than the two dates mentioned above. An upper limit for the construction of the barrow is given by a series of dates from a fractionated peat sample from the base of the ditch. These have a mean of I $30 \pm 55$ bc (UB-193A,C,F). Thus, while the barrow is clearly shown to be of Bronze Age, rather than Iron Age, date it has been possible to provide only a rather wide bracket for its construction. It is clear from the work at this site, however, that misleading results could be obtained from soils buried beneath peats where the overburden has been such as to allow the downwash of humic acids. The date of the humic acid fraction of the sample UB-195 referred to above, for instance, was $900 \pm 60 \mathrm{bc}$ (UB-195C), roughly a millennium younger than the date of the fine particulate fraction (UB-I $95 \mathrm{~F}$ ).

\section{HILLFORTS}

A series of five radiocarbon dates has been obtained from the famous hillfort at Navan, Co. Armagh, which is being excavated by D. M. Waterman. After Neolithic utilization of the site a ditch was dug to enclose a circular habitation area. Charcoal from the base of this ditch has given a date of $680 \pm 5 \circ$ bc (UB-I 88 ), suggesting that the enclosure was in use by the end of the Bronze Age. This conforms with the finding of the blade of a bronze socketed sickle in cobbling associated with the round houses in the enclosure. Charcoal from the wall slot of one of the later houses has given a date of $4 \mathrm{IO} \pm$ 45 bc (UB-203). Charcoal from above the natural silt of the ditch, which is applicable to the circular habitation area in general, has given a date of $395 \pm 5^{\circ}$ bc (UB-187). After the end of the occupation of the circular enclosure with round houses there is stratigraphic evidence of a period of disuse of the site. Thereafter, a massive structure of concentric rings of timbers was erected. Mr Waterman has shown that the structure was partially rebuilt, and finally deliberately burnt. Charcoal of hazel and other twigs which appear to have 


\section{NEW RADIOCARBON DATES FROM IRELAND}

been kindling material with which the outer wall was fired, has given a date of $265 \pm 50 \mathrm{bc}$ (UB-202). Charcoal from the destruction layer of the timber structure itself has given a date of $465 \pm 50$ bc (UB-I 86). In view of the younger date of the supposed kindling material it seems likely that the charcoal from the destruction layer is derived from the old, inner parts of the large structural timbers. No dates have been obtained from material within the huge composite mound that was finally thrown up over the site, but the occupations clearly belong to the pre-Roman Iron Age. The final burning of the timber structure appears at the moment to have been considerably earlier than legend would have us believe. A further series of samples from this site is to be dated.

Three samples have been dated from the hillfort on the Cathedral Hill in Armagh City traditionally associated with St Patrick. The site was excavated by Miss C. Warhurst and A. Harper. Twigs from the bottom of the ditch gave a date of $290 \pm 80$ ad (UB-283), while charcoal from an intermediate layer in the ditch filling gave a date of ${ }_{10} \pm 85 \mathrm{ad}$ (UB-284). The charcoal thus appears to have been from old wood but the date for the twigs suggests the possibility of pre-Christian activity. Charred twigs from a pit dug into the filled ditch gave a date of $520 \pm 85$ ad (UB-285). This spread of dates is conformable with finds from a metal workshop (Warhurst and Harper, forthcoming.)

\section{CRANNOGS}

A lake dwelling, or crannog, at Teeshan, Co. Antrim was destroyed by road works in 1968 after a rescue excavation by $R$. Warner and A. E. P. Collins. The finds, mostly unstratified, suggest occupation during Early Christian times. The $\mathrm{CI}_{4}$ date obtained from one of the heavy oak timbers from the crannog is $20 \pm 65$ bc (UB-266). The sample came from the middle of a 500-year floating tree-ring sequence worked out by M. G. L. Baillie. A more accurate dating of the structure will undoubtedly be possible when the tree-ring sequence can be connected with the series being extended backwards from the present.

A crannog in Mill Lough, Co. Fermanagh, was the subject of a summary rescue excavation by $R$. Warner in 1968 . Here a sample taken from the outer part of an oak trunk has been dated to $1265 \pm 80$ ad (UB-267). The structure, which is a typical 'Fermanagh Crannog' yielded 'crannog ware' pottery. The general attribution of this pottery to the medieval period is supported by the $\mathrm{CI}_{4}$ date and by the finding of leather shoes dating to medieval times.

\section{HISTORIC TIMES}

So far, no material has come to hand from Viking times. It is of interest, however, that a date of $915 \pm 75$ ad (UB-373) has been obtained for a level in a pollen diagram made by Mrs A. Goddard, where there are indications of clearance of upland scrub for pasture. Such a response to the Viking settlements has been envisaged by Mitchell (1956, 291).

Very few of the thousands of raths, or ringworks, that characterize the north Irish countryside have so far been excavated and evidence for their dating is very sparse. Undoubtedly, this is one problem of Irish archaeology that would repay an intensive programme of excavation and radiocarbon dating. So far, however, material from only one such farmstead has been dated. This site, at Mullaghbane, Co. Tyrone, was excavated by A. Harper. The results, however, are not unequivocal. Charcoal from the fossil soil beneath the bank of the rath, separated in the laboratory by $\mathrm{P}$. Q. Dresser, gave a date of $940 \pm$ II 5 bc (UB-39I). While it has been mooted that raths may have been in use as early as the Bronze Age, it is more likely in this case that the charcoal predates the ringwork. Humic acid extracted from the upper part of the same soil has given a date of $1125 \pm 85$ ad (UB-268). Because of the very thick overburden of clay it seems unlikely that this would have been contaminated by later humus. The date could indicate the maximum age of the ringwork but does not certainly do so. The lower part of the soil, contiguous with UB-39I, has given a date of $235 \pm 100$ ad (UB-390). This again suggests lack of humic acid downwash and, indeed, of any disturbance such as ploughing. The great disparity in age between these two 


\section{ANTIQUITY}

arbitrarily separated samples shows one hazard of using such soil material for dating.

Finally, a date has been obtained for the oak foundation timber of the entrance of the moated site at Kilmagoura, Co. Cork, excavated by R. E. Glasscock in 1967 (Glasscock, I968). The date obtained, $1225 \pm 70$ ad (UB-3I7), conforms well with a date in the late thirteenth to fourteenth century which has been suggested from the excavation evidence.
It is increasingly clear from the work on archaeological samples in the Belfast laboratory that the major problems of dating by the $\mathrm{C}_{4} 4$ method are in the field. The origin and composition of the material assayed is quite as important as its connexion with the artifact or monument it is intended to date. These two problems are no less important than the calibration of the radiocarbon dates themselves.

\section{BIBLIOGRAPHY}

ADDYMAN, P. V. I965. Coney Island, Lough Neagh: prehistoric settlement, Anglo-Norman castle and Elizabethan native fortress, Ulster fourn. Archaeol., xxviII, 78-101.

ApSIMON, A. M. I 969a. An early Neolithic house in Co. Tyrone, Fourn. Roy. Soc. Antiq. Ireland, $\mathrm{xcIx}, \mathrm{165-68}$

1969b. The earlier Bronze Age in the north of Ireland, Ulster fourn. Archaeol., xxxII, 28-72.

CASE, H. 1961. Irish neolithic pottery: distribution and sequence, Proc. Prehist. Soc., xxvII, I 74-233.

1969. Settlement-patterns in the North Irish Neolithic, Ulster Fourn. Archaeol., xxxII, 3-27.

ColliNs, A. E. P. 1965. Ballykeel Dolmen and Cairn, Co. Armagh, Ulster Fourn. Archaeol., xxviII, 47-70.

Collins, A. E. P. and B. C. S. WILson. I964. The excavation of a Court Cairn at Ballymacdermot, Co. Armagh, Ulster Fourn. Archaeol, xxvi, 3-22. EOGAN, G. I968. Excavations at Knowth, Co. Meath, I 968, Antiquity, XLIII, 8-I4.

GLASSCOCK, R. E. 1968. Report of excavation in 'Medieval Britain in 1967', Med. Archaeol., XII, I96-7.

MCAULAY, I. R. and W. A. WATtS. 196r. Dublin radiocarbon dates I, Radiocarbon, III, 26-38.
MAY, A. MCL. I953. Neolithic habitation site, stone circles and alignments at Beaghmore, Co. Tyrone, F. Roy. Soc. Antiq. Ireland, LxxxIII, I 74-193.

MITCHELL, G. F. 1956. Post-boreal pollen diagrams from Irish raised bogs, Roy. Irish Acad. Proc., LVIIB, 29I-3I4.

OLSON, E. A. and W. S. BROECKER. I 961. Lamont natural radiocarbon measurements VII, Radiocarbon, 3, 141-75.

PILCHER, J. R. 1969. Archaeology, palaeoecology and ${ }^{14} \mathrm{C}$ dating of the Beaghmore stone circle site, Ulster Yourn. Archaeol., xxxII, 73-92.

SMITH, A. G., G. W. PEARSON and J. R. PILCHER. 1970. Belfast radiocarbon dates $\mathrm{I}$ and II, Radiocarbon, I2, 285-97.

1971. Belfast radiocarbon dates III, Radiocarbon, ${ }_{3} 3$ (in press).

WARHURST, c. and A. HARPER. I971. Excavations in Castle Street, Armagh, Archaeol. Res. Pubs. (Northern Ireland), Belfast, HMSO (forthcoming).

Waterman, D. M. I965. The Court Cairn at Annaghmare, Co. Armagh, Ulster fourn. Archaeol., xxviri, 3-46.

WATTS, W. A. 196r. C-14 dating and the Neolithic in Ireland, Antiquity, xxxIv, I I I-16.
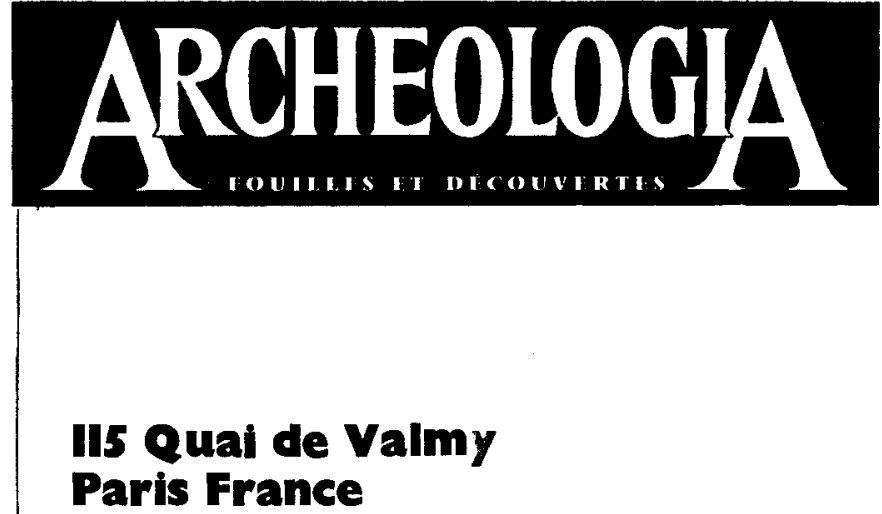

l'archéologie dans le monde et toute ce qui concerne les recherches historiques, artistiques et scientifiques sur terre et dans les mers free copy on request 